\title{
Evaluation of power Doppler sonography in acute cholecystitis to predict intraoperative findings: a prospective clinical study
}

\author{
Süleyman Çetinkünar, M.D., ${ }^{1}$ Hasan Erdem, M.D., ${ }^{1}$ Recep Aktimur, M.D., ${ }^{3}$ Gokhan Soker, M.D., ${ }^{2}$ \\ Hilmi Bozkurt, M.D., ${ }^{1}$ Enver Reyhan, M.D., ${ }^{1}$ Selim Sozen, M.D., ${ }^{1}$ Oktay İrkorucu, M.D., ${ }^{1}$
}

\begin{abstract}
1Department of General Surgery, Adana Numune Training and Research Hospital, Adana;
${ }^{2}$ Department of Radiology, Adana Numune Training and Research Hospital, Adana;

${ }^{3}$ Department of General Surgery, Samsun Training and Research Hospital, Adana
\end{abstract}

\begin{abstract}
BACKGROUND: This study aimed to evaluate the diagnostic value of gray-scale and power Doppler sonography for acute cholecystitis and show a correlation between sonographic and intraoperative findings, quantitively.

METHODS: Forty chronic and forty acute cholecystitis patients were examined. Early laparoscopic cholecystectomy was performed for acute cholecystitis. Demographic characteristics, sonographic findings, and adhesion scores were analyzed. Data were collected prospectively (clinicaltrials.gov: NCT02156947).

RESULTS: Wall thickness $(\geq 3 \mathrm{~mm})$ and vascularity increased in acute cholecystitis $(p<0.0 \mathrm{l}$ and $<0.0 \mathrm{I})$. Vascularity was found to be moderately correlated with adhesion $(p<0.01, r=0.59)$ but it did not affect the difficulty of the operation by means of perforation, conversion rate, and operation time. In addition, wall thickness did not correlate with adhesion formation $(p=0.36)$. Sensitivity and specifity of wall thickness and vascularity were found to be $96.9 \%, 72.7 \%$, and $68 \%, 87.2 \%$, respectively. When both diagnostic measurements were taken into account, sensitivity was calculated $69.7 \%$ and specificity reached up to $97.6 \%$.
\end{abstract}

CONCLUSION: Vascularity correlated with adhesion but failed to predict operation difficulty. Specificity of gray-scale sonography could be improved with power Doppler examination; however, desired diagnostic accuracy could not be obtained with only quantitive measurements of sonography.

Key words: Acute; cholecystitis; chronic; power Doppler; vascularity.

\section{INTRODUCTION}

For a long time, gray-scale sonography has generally been considered first-line diagnostic tool for patients with suspected gallbladder (GB) diseases. ${ }^{[l]}$ Moreover, it has been proven to be a valuable imaging technique in differential diagnosis for acute or chronic cholecystitis. ${ }^{[2]}$ In the presence of gallstones, sonographic findings such as GB wall thickening and the Mur-

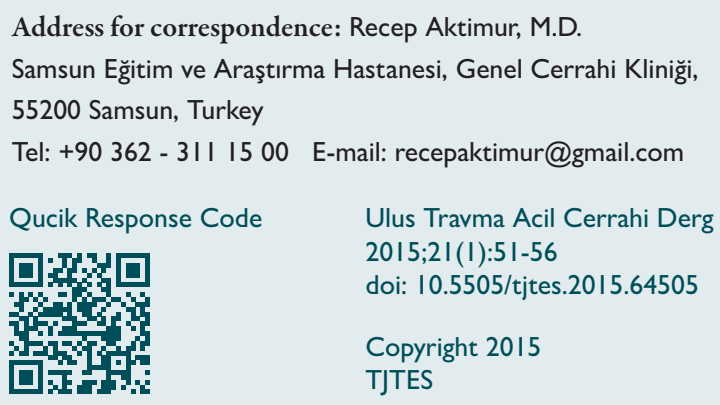

phy's sign has $95.2 \%$ sensitivity for the diagnosis of acute cholecystitis. ${ }^{[3]}$ In acute cholecystitis, GB wall thickness is caused by increased vascularity of the GB wall but in chronic cholecystitis it is caused by fibrosis. ${ }^{[4]}$ On the other hand, a number of conditions can cause GB wall thickness, such as pancreatitis, hepatitis, cirrhosis, and congestive heart failure. In order to increase the specificity of the diagnosis, determining the vascularity of the GB wall with Doppler sonography showed valuable diagnostic benefits in previous reports and diagnostic superiority was obtained especially with power Doppler sonography. ${ }^{[4,5]}$ Despite higher diagnostic capability of power Doppler sonography for the discrimination of acute cholecystitis from the chronic form, the real challenge is to determine the association between sonographic findings and predicting the difficulty of dissection and to help physician to make a clear decision for performing or not performing an emergent operation. So as to evaluate the diagnostic and prognostic value of gray-scale and power Doppler sonography for acute cholecystitis, it was our aim to show a correlation between 
quantitive sonographic findings and intraoperative adhesion scale and compare it with the chronic cholecystitis as a control group.

\section{MATERIALS AND METHODS}

A total of eighty cholecystitis patients (40 symptomatic chronic, 40 acute) treated in our tertiary care center between January 2012 and July 2013 constituted the study groups. An informed consent was taken from all patients before they were included into the study. The protocol of this prospective clinical study was approved by the local Institutional Review Board (4/16.0I.2012). Data were collected prospectively (clinicaltrials.gov registration ID: NCT02 I56947). The occurrence of clinical signs in the first 72-96 hours after the onset of symptoms was termed as acute cholecystitis. The diagnosis of acute cholecystitis was made on clinical, sonographic and laboratory findings. Acute right upper quadrant abdominal pain with positive Murphy's sign, fever, leukocytosis were considered clinically; distended GB, presence of gallstones or sludge, GB wall thickness of 3-mm or more, and sonographic Murphy's sign were considered sonographically significant. If a patient was diagnosed with acute cholecystitis, he or she was informed about early laparoscopic cholecystectomy (LC) and if LC was accepted, the patient was included into the study and operated in the first 24 hours following the diagnosis. Detected choledocholithiasis and patients $<18$ years of age were excluded. No age limit was specified. Age and sex were recorded.

All patients were examined by a single radiologist with Mindray DC-7 ultrasonography device and a $3.5 \mathrm{MHz}$ abdominal transducer, following a fasting period of a minimum of 6 hours. Gray-scale abdominal US examination was followed by power Doppler examinations in which quantitative measurements were made according to previous report of Uggowitzer et al. ${ }^{[5]}$ Vascularity was 0 if there was no vessel within the GB wall; vascularity was + when no more than two signals per centimeter were detected within the wall; vascularity was ++ when there were multiple scattered signals; and continuously depicted vessels for a length of at least $25 \mathrm{~mm}$ were assigned a vascularity +++. In addition, sonographic $G B$ wall thickness and free fluid on the GB fossa were recorded.

All operations were performed by the senior staff of our clinic. The technique used for LC was the conventional fourtrocar approach. Inability to provide critical view of safety was considered an indication for conversion to open cholecystectomy. GB adhesion score developed by Akoğlu et al. and intraoperative findings of patients were assessed and recorded by one surgeon (S. C.). ${ }^{[6]}$ Adhesion scoring scale is based on the degree of inflammatory changes in the GB as a guide for predicting the course of operation. During exploration, the extent and thickness of the adhesions in the GB region were graded as follows: grade I, no adhesions; grade II, flimsy adhesions that permit easy dissection; grade III, chronic pericholecystitis and pericholecystic fibrosis making dissection difficult but permitting visualization of the anatomy; and grade IV, thickened GB wall and anatomical distortion due to dense adhesions around the $G B$, which do not permit safe dissection. Adhesion score, GB perforation during dissection, conversion to open cholecystectomy, operation time, drain usage and intraoperative complications were recorded. Operation time was calculated from the initiation of skin incision to the last skin suture.

Postoperative pain measured by visual analog scale (VAS) was recorded.

Data were presented as mean \pm standard deviation (SD) or median (min-max) according to the distribution pattern. Student's $t$ test and Mann-Whitney $U$ test were used for the comparison of continuous variables. Chi-Square test and Fisher's Exact test were used for the comparison of categorical variables. Kendall's Tau-b Correlation test was used for correlation analysis of categorical variables. A $P$ value less than 0.05 was considered statistically significant. Statistical analyses were performed with SPSS Version 16.00 (Chicago, IL, USA).

\section{RESULTS}

All patients were operated successfully without any intraoperative complications. Seven (17.5) of the forty patients in the acute cholecystitis group were crossed over to chronic cholecystitis group after the pathological assessment of the specimens. All statistical analyses were conducted according to pathologically proven chronic $(n=47)$ and acute cholecystitis $(n=33)$.

Age and sex were similar between the groups. Demographic and descriptive characteristics of the groups are presented in Table I.

For easy interpretation of the association, sub-classification for vascularity and intraoperative adhesion scale were performed. After the pilot statistical analysis with different combinations, mild / severe $(0,+/++,+++$; and Grade I, II/Grade III, IV) sub-classification for vascularity and intraoperative adhesion scale was used.

Wall thickness ( $\geq 3 \mathrm{~mm}$ ) and vascularity were found to be increased in acute cholecystitis $(\mathrm{p}<0.0 \mathrm{I}$ and $<0.0 \mathrm{I})$.

Vascularity was found to be moderately correlated with adhesion in acute cholecystitis $(p<0.01, r=0.59)$ but wall thickness did not reveal any correlation $(p=0.36)$.

In acute cholecystitis patients, according to vascularity and adhesion grade, GB perforation, conversion and operation time were not different $(p=0.07,0.99 ; 0.99,0.99$; and 0.35 , 0.18 , respectively). Drain usage was found to be statistically 
Table I. Demographic and descriptive characteristics of the groups

\begin{tabular}{|c|c|c|c|c|c|c|c|}
\hline \multirow[t]{2}{*}{ Pathologic diagnosis } & \multicolumn{3}{|c|}{ Chronic cholecystitis } & \multicolumn{3}{|c|}{ Acute cholecystitis } & \multirow[t]{2}{*}{$\mathbf{p}$} \\
\hline & $\mathbf{n}$ & $\%$ & Mean \pm SD & $\mathbf{n}$ & $\%$ & Mean $\pm S D$ & \\
\hline Number of patients & 47 & & & 33 & & & \\
\hline Age (years) & & & $48.8 \pm 14.2$ & & & $52.1 \pm 11.2$ & 0.26 \\
\hline \multicolumn{8}{|l|}{ Gender } \\
\hline Female & 36 & 76.6 & & 22 & 66.7 & & \\
\hline Male & II & 23.4 & & 11 & 33.3 & & 0.33 \\
\hline GB wall thickness & & & $2.2 \pm 0.7$ & & & $4.6 \pm 1$ & $<0.01$ \\
\hline \multicolumn{8}{|l|}{ GB wall vascularity } \\
\hline 0 & 8 & 17 & & I & 3 & & $<0.01$ \\
\hline+ & 33 & 70.2 & & 8 & 24.2 & & \\
\hline++ & 6 & 12.8 & & 17 & 51.5 & & \\
\hline+++ & 0 & 0 & & 7 & 21.3 & & \\
\hline Free fluid on GB fossa & 1 & 2.1 & & 7 & 21.3 & & $<0.01$ \\
\hline \multicolumn{8}{|l|}{ GB adhesion scoring scale } \\
\hline Grade I & 20 & 42.6 & & 4 & 12.1 & & 0.01 \\
\hline Grade II & 21 & 51.1 & & II & 33.3 & & \\
\hline Grade III & 2 & 4.2 & & 15 & 45.5 & & \\
\hline Grade IV & 1 & 2.1 & & 3 & 9.1 & & \\
\hline Operation time & & & $78.7 \pm 20$ & & & $79.8 \pm 26.3$ & 0.78 \\
\hline Conversion to open & 1 & 2.1 & & I & 3 & & 0.99 \\
\hline Perforation & 5 & 12.8 & & 7 & 21.3 & & 0.31 \\
\hline Drain usage & 9 & 19.1 & & 15 & 45.5 & & 0.01 \\
\hline Postop pain (VAS), median (min-max) & 3 & $0-9$ & & 5 & $2-8$ & & $<0.01$ \\
\hline
\end{tabular}

significant regarding the vascularity and adhesion in acute cholecystitis $(p=0.02$ and 0.05$)$ while postoperative pain score was different with adhesion $(p<0.01)$.

Sensitivity and specifity of increased wall thickness and vascularity for the proof of pathological diagnosis of acute cholecystitis were found to be $96.9 \%, 72.7 \%$ and $68 \%, 87.2 \%$, respectively. When both diagnostic measurements were taken into account, sensitivity was calculated $69.7 \%$, and specificity reached $97.6 \%$. Receiver operating characteristic (ROC) analysis of the patients with pathologically confirmed acute cholecystitis is shown in Figure I.

\section{DISCUSSION}

Radiological discrimination between chronic and acute cholecystitis is important in terms of decision making. If the decision is made as acute cholecystitis, a cholecystectomy should be performed within the first 72 hours for more satisfactory results for the patients and the surgeons. ${ }^{[7,8]}$ In the past, laparoscopic cholecystectomy was considered a relative contraindication in the treatment of acute cholecystitis. ${ }^{\left[{ }^{[]}\right.}$With the accumulating experience in laparoscopic surgery, laparoscopic cholecystectomy (LC) has become the gold standard treatment for benign biliary diseases even in acute cases. It has been shown that early laparoscopic cholecystectomy during acute cholecystitis is safe and shortens total hospital stay. ${ }^{[10]}$ Although laparoscopic approach to acute cholecystitis has a number of advantages, timing of the operation and intraoperative findings of GB wall inflammation are critical for performing a safe cholecystectomy. In the beginning of gallbladder wall inflammation, adhesions are easily dissected from the liver bed within the oedematous periton around the gallbladder. Progression in the inflammation makes the dissection difficult and increases the perforation rate of the gallbladder. ${ }^{[1]}$ Furthermore, distortion of the anatomy by severe inflammation and related fibrous adhesions increase the risk of bleeding and bile duct injury. ${ }^{[4]}$ These findings may lead the surgeon to convert LC to an open cholecystectomy. In our patients, intraoperative bleeding or bile duct injury were not encountered. Various conversion rates have been reported in the literature, ranging from $4.9 \%$ to $29 \% .^{\left[{ }^{12-14]}\right.}$ With limited number of patients, our conversion rates were $2.1 \%$ and $3 \%$, in 


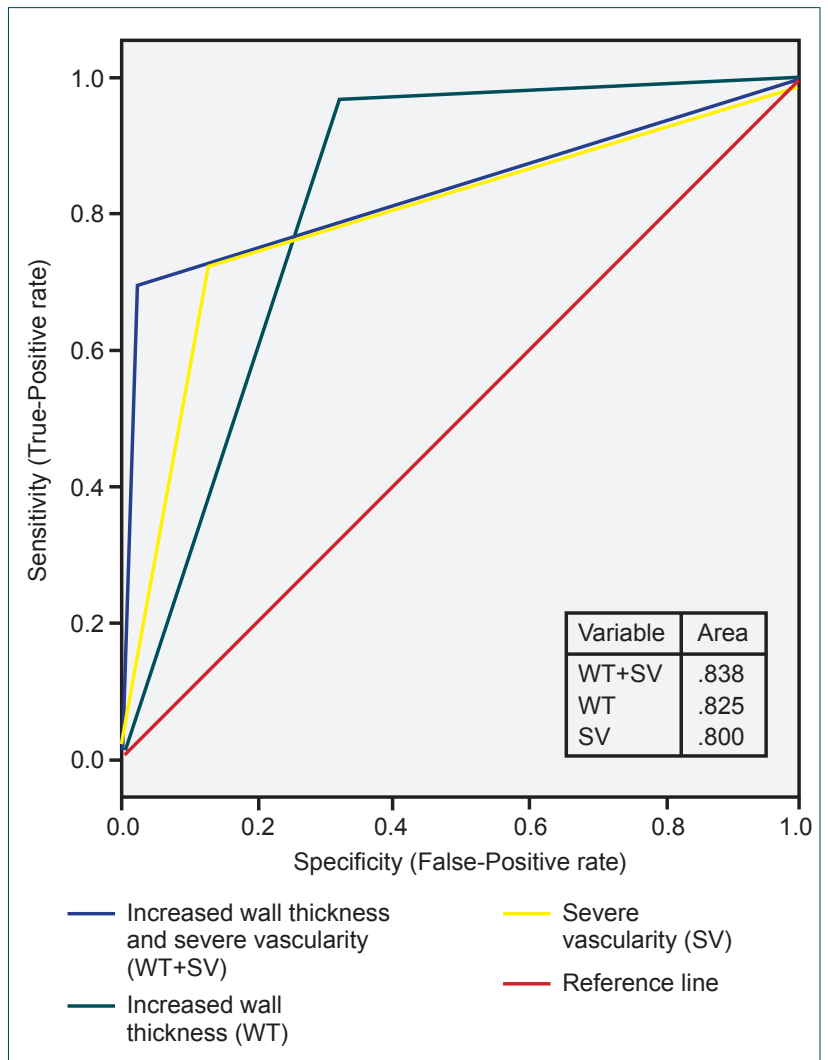

Figure 1. Graph shows that ROC analysis of power Doppler sonography detected severe vascularity $(++,+++)$, Gray-scale sonography detected increased wall thickness $(\geq 3 \mathrm{~mm})$, and both modalities had positive conditions for differentiating patients with acute cholecystitis.

chronic and acute cholecystitis, respectively. Although there were high conversion rates in some studies, recent and large reports have shown marked decrease over time. Sakpal et al. have stated that male patients $>50$ years of age and operated by low-volume surgeons have a higher rate of conversion. ${ }^{[12]}$ In our study, obtained lower rate of conversion could be associated with all of these factors since most of our patients were female, the median age was 51 years (19-79), and all operations were performed by our experienced senior staff. In recent years, drain usage in surgery has been a commonly queried issue and it has been shown that prophylactic drain insertion adds no benefits even in complicated acute cholecystitis. ${ }^{[15]}$ However, our drain usage rate of $45.5 \%$ in acute cholecystitis was higher than the reported rate of $36.8 \%{ }^{[15]}$

Well known and commonly used first-line diagnostic tool for the diagnosis of acute cholecystitis was Gray-scale sonography. Patient selection, operator experience, and the differences in histopathologic diagnosis resulted in a wide range of diagnostic accuracy regarding the use of gray-scale sonography, ranging from $60 \%$ to $98 \%{ }^{[2,3,16]}$ Increased wall thickness ( $\geq 3 \mathrm{~mm}$ ), being the only quantitive measurement of gray-scale sonography, has demonstrated a $44 \%$ positive predictive value for the diagnosis of acute cholecystitis. ${ }^{[4]}$ In order to exclude other causes of wall thickness and measure the direct effect of underlying pathophysiology of acute cholecystitis, GB wall vascularity has been extensively evaluated in the literature with the use of color and power Doppler sonography. ${ }^{[4,5,17,18]}$ Paulson et al. have stated that color Doppler sonography for the diagnosis of acute cholecystitis Is nonspecific as thickening of the wall. ${ }^{[18]}$ On the other hand, with the use of power Doppler sonography, a significant diagnostic superiority was put forward in previous reports. ${ }^{[5,17]}$ However, the quantitive measurement of GB wall vascularity and its association with pathologically proven acute cholecystitis has been reported by only one study. ${ }^{[5]}$ To the best of our knowledge, this is the first prospective comparative study aiming to evaluate the association between preoperative sonographic (gray-scale and power Doppler) findings and intraoperative adhesion grade, quantitively.

According to some authors, gray-scale sonography have revealed up to $99 \%$ specificity and $97 \%$ sensitivity. ${ }^{[19,20]}$ In this study, for the purpose of excluding the inter-observer variability, the sensitivity and specificity of the diagnostic tools were calculated according to quantitive parameters, increased GB wall thickness ( $\geq 3 \mathrm{~mm}$ ) for gray-scale and severe vascularity for power Doppler sonography. Increased wall thickness showed $96.9 \%$ sensitivity and $68 \%$ specificity in our patients. With the use of power Doppler sonography, Soyer et al. have shown remarkable increase in sensitivity and specificity of gray-scale sonography, $86 \%, 99 \%$; and $95 \%, 100 \%$, respectively. ${ }^{[4]}$ Uggowitzer et al. have defined a scoring system for power Doppler sonography aiming to score the vascularity of the GB wall on a scale of 0 to +++ . They have stated severe vascularity $(++,+++)$ in $96 \%$ of all acute cholecystitis patients while this study indicated $72.8 \%$. Additionally, they have reported $95 \%$ sensitivity and $86 \%$ specificity with severe vascularity. ${ }^{[5]}$ In the present study, severe vascularity was $72.7 \%$ sensitivity and $87.2 \%$ specificity for the diagnosis of acute cholecystitis. In spite of the low sensitivity and specificity rate of our study, it must be noted that whole features of both modalities were used for primary diagnosis and decision making; however, the most objective and less operator-dependent findings of the diagnostic tools were analyzed. Besides, all of our patients were examined by one radiologist. From this aspect, our results were similar to the sub-classified result of Uggowitzer et al., $73 \%$ sensitivity and $67 \%$ specificity, for only GB wall thickness. ${ }^{[5]}$ When both diagnostic measurements were taken into account, sensitivity was calculated $69.7 \%$ and specificity reached up to $97.6 \%$.

Despite the importance of the association between diagnostic tool and pathological proof of the diagnosis, from a surgeon's perspective, predicting the difficulty of the operation is uppermost valuable. ${ }^{[21]} A$ number of previous studies have reported a relation between increased GB wall thickness and dissection difficulty. ${ }^{[21-23]}$ Pehlivan et al. have indicated high postoperative complication rate with increased wall thickness. ${ }^{[20]}$ In acute cholecystitis patients, a moderate correla- 
tion was found between severe vascularity and severe intraoperative adhesion grade but increased wall thickness was not correlated with the presence of adhesion. The positive correlation between severe vascularity and severe adhesion formation did not affect the difficulty of the operation in our patients by means of GB perforation, conversion rate and operation time. Drain usage increased in the presence of severe vascularity and severe adhesion. Postoperative pain did not increase in severe vascularity but it increased in the patients developing severe adhesions.

It must be noted that our study had some strong and weak points. For the elimination of inter-operator changes, one radiologist examined all patients, one surgeon assessed GB adhesion score in all operations, and all measurements were based on quantitive scoring systems. Additionally, in order to overcome heterogeneities in previous studies, regarding the sample size and the time frame between diagnosis to operation, patients with confirmed diagnosis of acute cholecystitis were operated in the first 24 hours. On the other hand, the difficulties of laparoscopic cholecystectomy were indirectly assessed in terms of GB perforation, conversion rate and operation time; however, all relevant factors affecting the difficulty of the operation, such as body mass index (BMI), symptom duration, number of right-upper quadrant pain attack, were not evaluated. Moreover, our sample size was relatively small, especially for the evaluation of rare complications of surgery.

\section{Conclusion}

Our results indicated that GB wall vascularity correlated with adhesion formation but failed to predict difficulties in the dissection of the operation. The diagnostic specificity of grayscale sonography for acute cholecystitis could be improved with additional power Doppler examination. However, desired diagnostic accuracy of preoperative sonography could not be obtained with only quantitive measurements.

\section{Conflict of interest: None declared.}

\section{REFERENCES}

1. Carroll BA. Preferred imaging techniques for the diagnosis of cholecystitis and cholelithiasis. Ann Surg 1989;210:1-12. CrossRef

2. Laing FC, Federle MP, Jeffrey RB, Brown TW. Ultrasonic evaluation of patients with acute right upper quadrant pain. Radiology 1981;140:449. 55. CrossRef

3. Ralls PW, Colletti PM, Lapin SA, Chandrasoma P, Boswell WD Jr, Ngo C, et al. Real-time sonography in suspected acute cholecystitis. Prospective evaluation of primary and secondary signs. Radiology 1985;155:76771. CrossRef

4. Soyer P, Brouland JP, Boudiaf M, Kardache M, Pelage JP, Panis Y, et al. Color velocity imaging and power Doppler sonography of the gallbladder wall: a new look at sonographic diagnosis of acute cholecystitis. AJR Am J Roentgenol 1998;171:183-8. CrossRef

5. Uggowitzer M, Kugler C, Schramayer G, Kammerhuber F, Gröll R,
Hausegger KA, et al. Sonography of acute cholecystitis: comparison of color and power Doppler sonography in detecting a hypervascularized gallbladder wall. AJR Am J Roentgenol 1997;168:707-12. CrossRef

6. Akoğlu M, Ercan M, Bostanci EB, Teke Z, Parlak E. Surgical outcomes of laparoscopic cholecystectomy in scleroatrophic gallbladders. Turk J Gastroenterol 2011;22:183-9.

7. Hunter JG. Acute cholecystitis revisited: get it while it's hot. Ann Surg 1998;227:468-9. CrossRef

8. Lo CM, Liu CL, Fan ST, Lai EC, Wong J. Prospective randomized study of early versus delayed laparoscopic cholecystectomy for acute cholecystitis. Ann Surg 1998;227:461-7. CrossRef

9. Phillips EH, Carroll BJ, Fallas MJ. Laparoscopically guided cholecystectomy: a detailed report of the first 453 cases performed by one surgical team. Am Surg 1993;59:235-42.

10. Zhou MW, Gu XD, Xiang JB, Chen ZY. Comparison of clinical safety and outcomes of early versus delayed laparoscopic cholecystectomy for acute cholecystitis: a meta-analysis. ScientificWorldJournal 2014;2014:274516.

11. Assaff Y, Matter I, Sabo E, Mogilner JG, Nash E, Abrahamson J, et al. Laparoscopic cholecystectomy for acute cholecystitis and the consequences of gallbladder perforation, bile spillage, and "loss" of stones. Eur J Surg 1998;164:425-31. CrossRef

12. Sakpal SV, Bindra SS, Chamberlain RS. Laparoscopic cholecystectomy conversion rates two decades later. JSLS 2010;14:476-483. CrossRef

13. Kiviluoto T, Sirén J, Luukkonen P, Kivilaakso E. Randomised trial of laparoscopic versus open cholecystectomy for acute and gangrenous cholecystitis. Lancet 1998;351:321-5. CrossRef

14. Sikora SS, Kumar A, Saxena R, Kapoor VK, Kaushik SP. Laparoscopic cholecystectomy--can conversion be predicted? World J Surg 1995;19:858-60. CrossRef

15. Bawahab MA, Abd El Maksoud WM, Alsareii SA, Al Amri FS, Ali HF, Nimeri AR, et al. Drainage vs. non-drainage after cholecystectomy for acute cholecystitis: a retrospective study. J Biomed Res 2014;28:240-5.

16. Martínez A, Bona X, Velasco M, Martín J. Diagnostic accuracy of ultrasound in acute cholecystitis. Gastrointest Radiol 1986;11:334-8. CrossRef

17. Draghi F, Ferrozzi G, Calliada F, Solcia M, Madonia L, Campani R. Power Doppler ultrasound of gallbladder wall vascularization in inflammation: clinical implications. Eur Radiol 2000;10:1587-90. CrossRef

18. Paulson EK, Kliewer MA, Hertzberg BS, Paine SS, Carroll BA. Diagnosis of acute cholecystitis with color Doppler sonography: significance of arterial flow in thickened gallbladder wall. AJR Am J Roentgenol 1994;162:1105-8. CrossRef

19. Ji W, Li LT, Li JS. Role of laparoscopic subtotal cholecystectomy in the treatment of complicated cholecystitis. Hepatobiliary Pancreat Dis Int 2006;5:584-9.

20. Pehlivan T, Alper Cevik A, Ateş E. Relationships among ultrasonographic and demographic, clinical, laboratory findings of patients with acute cholecystitis. Ulus Travma Acil Cerrahi Derg 2005;11:134-40.

21. Stanisic V, Milicevic M, Kocev N, Stojanovic M, Vlaovic D, Babic I, et al. Prediction of difficulties in laparoscopic cholecystectomy on the base of routinely available parameters in a smaller regional hospital. Eur Rev Med Pharmacol Sci 2014;18:1204-11.

22. Fried GM, Barkun JS, Sigman HH, Joseph L, Clas D, Garzon J, et al. Factors determining conversion to laparotomy in patients undergoing laparoscopic cholecystectomy. Am J Surg 1994;167:35-41. CrossRef

23. Sakuramoto S, Sato S, Okuri T, Sato K, Hiki Y, Kakita A. Preoperative evaluation to predict technical difficulties of laparoscopic cholecystectomy on the basis of histological inflammation findings on resected gallbladder. Am J Surg 2000;179:114-21. CrossRef 
KLINİK ÇALIŞMA - ÖZET

\section{Akut kolesistitte intraoperatif bulguları öngörmede power Doppler ultrasonun değerlendirilmesi: İleriye yönelik klinik çalışma \\ Dr. Süleyman Çetinkünar, ${ }^{1}$ Dr. Hasan Erdem, ${ }^{1}$ Dr. Recep Aktimur, ${ }^{3}$ Dr. Gokhan Soker, ${ }^{2}$ Dr. Hilmi Bozkurt, ${ }^{1}$ Dr. Enver Reyhan, ${ }^{1}$ Dr. Selim Sozen, ${ }^{1}$ Dr. Oktay İrkorucu ${ }^{1}$}

${ }^{1}$ Adana Numune Eğitim ve Araştırma Hastanesi, Genel Cerrahi Kliniği, Adana;

${ }^{2}$ Adana Numune Eğitim ve Araştırma Hastanesi, Radyoloji Kliniği, Adana;

${ }^{3}$ Samsun Eğitim ve Araştırma Hastanesi, Genel Cerrahi Klinigi, Samsun

AMAÇ: Akut kolesistit tanıında gri-skala ve power Doppler ultrasonografinin değerini belirlemek için kantitatif sonografik ve intraoperatif bulgular arasındaki ilişkiyi göstermek amaçlandı.

GEREÇ VE YÖNTEM: Kırk kronik, 40 akut kolesistit hastası değerlendirildi. Akut kolesistit hastalarına erken laparoskopik kolesistektomi uygulandı. Demografik özellikler, sonografik bulgular ve adezyon skoru incelendi. Veriler ileriye yönelik olarak toplandı (clinicaltrials.gov: NCT02 I56947).

BULGULAR: Duvar kalınlığı $(\geq 3 \mathrm{~mm})$ ve vaskülarite akut kolesistitte artmıştı $(p<0.0$ I ve $<0.01)$. Vaskülarite ile adezyon arasında orta düzey ilişki saptanmasına rağmen $(p<0.01, r=0.59)$ perforasyon, konversiyon ve operasyon süresi açısından ilişki saptanmadı. Duvar kalınlığı adezyon gelişimi ile ilişkili değildi $(p=0.36)$. Duvar kalınlığı ve vaskülarite için duyarlılık ve özgüllük sırasıyla: \%96.9, \%72.7 ve \%68, \%87.2 idi. Her iki tanısal değerlendirme birleştirildiğinde duyarlılı \%69.7 iken, özgüllük \%97.6’ya çıkmaktaydı.

TARTIŞMA: Vaskülarite, adezyon gelişimi ile ilişkili, ancak operasyon zorluğunu belirlemede yetersiz idi. Gri-skala ultrasonografinin özgüllüğünün power Doppler inceleme ile artırılabileceği görüldü, ancak istenilen tanısal doğruluğa sadece kantitatif ultrasonografik bulgular ile ulaşılamayacağı anlaşıldı.

Anahtar sözcükler: Akut; kolesistit; kronik; power Doppler; vaskülarite.

Ulus Travma Acil Cerrahi Derg 20I5;2I (I):5I-56 doi: 10.5505/tjtes.20I5.64505 